\title{
MITOLOGI KESENIAN NINI THOWONG
}

\author{
Ulivia \\ Program Pascasarjana, Universitas Negeri Yogyakarta \\ E-mail: viauli@rocketmail.com
}

\begin{abstract}
Abstrak
Kesenian Nini Thowong menjadi seni tradisi masyarakat Grudo sebagai permainan meminta keselamatan. Nini Thowong yang menjadi karya seni dengan unsur ritual yang tinggi dengan memasukan roh kedalam boneka. Hal ini antara lain berfungsi sebagai mitos untuk menyembuhkan penyakit. Nini Thowong terdiri dari dua kata, nini dan thowong. Nini dalam bahasa Jawa artinya nenek, dan thowong diartikan kosong. Nini Thowong adalah seorang perempuan yang sudah tua (roh halus) dan menempati tempat boneka yang masih kosong. Benda ini kemudian digunakan untuk memanggil roh halus agar mau menempatinya. Penelitian ini merupakan penelitian deskriptif, yang mendeskripsikan Mitos Nini Thowong. Penelitian ini menggunakan penelitian kualitatif karena bermaksud untuk mendeskripsikan, menginterpretasi dan menganalisis kondisikondisi yang terjadi secara mendalam, tanpa mengubah fakta yang terjadi. Secara semiotik, Nini Thowong merupakan media penyampaian pesan keagamaan lewat lagu-lagu yang dinyanyikan. Melalui fisik boneka Nini Thowong, antara lain bermakna bahwa dalam diri manusia terdapat sifat baik yang dilambangkan dengan warna putih dan buruk dengan warna hitam. Melalui sesaji antara lain bermakna adanya cita-cita luhur, untuk membangun bangsa dan negara.
\end{abstract}

Kata kunci: mitologi, Nini Thowong, roh

\section{THE MYTHOLOGY OF NINI THOWONG ART}

\begin{abstract}
Nini Thowong art becomes the Grudo's traditional art as a game asking for welfare. Nini Thowong is a work of art with high ritual elements by entering spirits into dolls. This, among other things, serves as a myth to cure illness. Nini Thowong consists of two words, nini and thowong. Nini in Javanese means grandmother, and thowong means empty. Nini Thowong is an old woman (ghost) that uses an empty doll as its place to live. This object is then used to call upon spirits to make them use it. This research is a descriptive study, which describes the myth of Nini Thowong. This study uses qualitative research because it intends to describe, interpret and analyze conditions that occurs, depthly, without changing the facts. In semiotic terms, Nini Thowong is a medium to deliver religious messages through its songs. Through Nini Thowong, it implies that there are good values within person which is symbolized by white and bad in black. Through sesaji or offerings, means the noble goals to build the nation and state do exist.
\end{abstract}

Keywords: mythology, Nini Thowong, spirit

\section{PENDAHULUAN}

Indonesia adalah negara yang terdiri dari beberapa pulau. Setiap pulau memiliki suku bangsa dan kebudayaan yang beraneka ragam. Salah satu keanekaragaman budaya adalah dalam seni tradisional. Secara umum, seni tradisi yang dimiliki kelompok etnik di Nusantara tidak dapat lepas dari konteks 
ritualitas dan sakralitas. Berbicara tentang wacana seni dapat diartikan sebagai paradigma atau perspektif untuk menafsirkan, memahami dan menjelaskan suatu fenomena seni atau kesenian (Shri, 1998:18). Kebudayaan itu sendiri adalah suatu serangkaian kegiatan yang dilakukan manusia sebagai bentuk hasil cipta, rasa, dan karsa manusia yang berguna untuk mencapai pemenuhan kehidupan manusia (Koentjaningrat, 2009: 165).

Kesenian Nini Thowongyang menjadi karya seni dengan unsur ritual yang tinggi dengan memasukan roh kedalam boneka tersebut, salah satu fungsinya sebagai mitos untuk menyembuhkan penyakit (wawancara Mbah Paeran, tanggal 7 Mei 2017). Nini Thowong sudah menjadi seni tradisi masyarakat Grudo sebagai permainan meminta keselamatan. Suwardi (2008: 2), menyatakan bahwa orang Jawa memang tidak lepas dari kekuatan roh. Dunia roh itu diyakini oleh orang Jawa memiliki kekuatan magis dalam membantu manusia. Nini Thowong termasuk seni pertunjukan yang menggunakan roh karena dianggap memiliki kekuatan yang dapat membantu manusia. Wawancara dengan Mbah Paeran (tanggal 7 Mei 2017), mengatakan bahwa suatu permainan Nini Thowong dipandang sebagai kesenian yang penuh dengan hal-hal yang keramat (wingit). Mbah Paeran adalah pawang yang memimpin jalannya pertunjukan Nini Thowong. Greertz (dalam Suwardi 2008: 6), menyatakan bahwa pawang adalah seorang abangan (orang yang kejawennya kuat).

Faktor lain yang menarik adalah adanya aspek mistik yang terdapat dalam permainan Nini Thowong dengan memangil roh kemudian dimasukan dalam boneka tersebut. Keberadaan fenomena kesenian itu sebagai media isyarat pencarian obat dengan melakukan serangkaian pertunjukan dengan bantuan roh. Nini Thowong tidak hanya untuk penyembuhan penyakit tetapi sebagai permainan tradisional. Pertunjukan Nini Thowong dimainkan oleh ibu-ibu yang memegang boneka dengan menari yang dipimpin oleh pawang. Boneka Nini Thowong itu dapat bergeleng-geleng, mengangguk, meloncat-loncat, berputar, dan kedua tangannya melambai-lambai. Penonton dalam pertunjukan Nini Thowong harus menjaga sopan santun, dalam tindakan dan ucapan, karena jika ada penonton yang ngrasani maka Nini Thowong akan marah dan membenturkan badannya ke penonton tersebut.

Nini Thowong terdiri atas dua kata nini dan thowong. Nini dalam bahasa Jawa artinya embah wedok yaitu orang perempuan yang sudah lanjut usia atau sudah nenek. Sementara thowong diartikan kosong (Sujarno, 2002: 228).Dengan demikian Nini Thowong adalah seorang perempuan yang sudah tua (roh halus) dan menempati tempat yang masih kosong, yakni boneka. Benda ini kemudian digunakan untuk memanggil roh halus agar mau menempatinya.Berdasar paparan tersebut, tulisan ini akan mengungkap mengenai mitos yang ada dalam kesenian Nini Thowong yang berada di dusun Grudo, dengan rumusan masalah: bagaimana mitos yang terdapat dalam kesenian Nini Thowong? Penelitian ini bertujuan untuk mengetahui apa saja mitos yang ada dalam kesenian Nini Thowong.

\section{KAJIAN TEORITIK Pengertian Mitos}

Dalam Kamus Besar Bahasa Indonesia, mitos diartikan sebagai "cerita suatu bangsa tentang dewa dan pahlawan zaman dahulu yang mengandung penafsiran tentang asalusul semesta alam, manusia, dan bangsa itu sendiri yang mengandung arti mendalam yang diungkapkan dengan cara gaib" (Tim Penyusun 1998: 660-661). Definisi ini senada dengan definisi yang dijelaskan dalam Dictionary of Religious,dalam kamus ini mitos didefinisikan sebagai:

"Narrative, usually traditional, in which, events are described as deeds of god, heroes, or other super superhuman beings; i.e. events in the realm of nature or history are attributed to causes not acceptable in current scientific or historical explanation" (Hinnells 1984: 225) (cerita-cerita yang bersifat tradisional dimana kejadiankejadian dijelaskan sebagai perbuatanperbuatan dewa, pahlawan, ataupun 
manusia-manusia hebat lainnya; yakni kejadian-kejadian dalam realm alam atau sejarah dihubungkan dengan sebab-sebab yang tidak bisa diterima dalam penjelasan ilmiah maupun penjelasan sejarah).

Mitos pada dasarnya bersifat religius, karena memberi rasio pada kepercayaan dan praktik keagamaan. Masalah yang dibicarakan adalah masalah-masalah pokok kehidupan manusia, dari mana asal kita dan segala sesuatu yang ada didunia ini, mengapa kita disini,dan kemana tujuan kita. Pada sebagian masyarakat yang masih mempercayai nilai sakral dari mitos, mitos berfungsi sebagai alat untuk mengontrol moral dan perilaku masyarakat. Berbagai contoh mitos di Indonesia dapat dijadikan contoh seberapa besar fungsi mitos atas tingkah laku, sikap, dan nilai moral yang terkandung di dalamnya.

Mitos mempunyai fungsi-fungsi tertentu. Diantaranya ialah: a) Proses penyadaran akan kekuatan ghaib. Mitos bukanlah informasi tentang kekuatan gaib, tetapi cara mengantisipasi, mempelajari, dan berelasi dengannya. b) Mamberi garansi bagi kekinian. Mitos mempresentasikan berbagai peristiwa yang pernah ada dan mengandung saran serta antisipasi bagi kekinian. c) Mitos merentangkan cakrawala epistemologis dan ontologis tentang realitas. Mitos memberikan penggambaran tentang dunia, tentang asal-mulanya, tetapi bukan seperti ilmu sejarah modern. Ruang dan waktu mitologis hanyalah konteks untuk berbicara tentang awal dan akhir, atau asal muasal dan tujuan kehidupan, dan bukan ruang dan waktu faktual (Simon, 2006:45).

Menurut Prof. Dr. C. A. Van Peursen, mitos ialah sebuah cerita yang memberikan pedoman dan arah tertentu kepada sekelompok orang. Cerita itu dapat dituturkan, tetapi juga dapat diungkapkan lewat tari-tarian atau pementasan wayang misalnya. Inti-inti cerita itu adalah lambang-lambang yang mencetuskan pengalaman manusia purba, lambang-lambang kebaikan dan kejahatan, hidup dan kematian, dosa dan penyucian, perkawinan, dan kesuburan, firdaus dan akhirat. Mitos semacam tahayul sebagai akibat ketidaktahuan manusia, tetapi bawah sadarnya memberitahukan tentang adanya sesuatu kekuatan yang menguasai dirinya serta alam lingkungannya.

\section{Kesenian Nini Thowong}

Di Kabupaten Bantul terdapat dua kesenian Nini Thowong, yaitu di dusun Grudo dan dusun Candran. Nini Thowong yang berada di dusun Grudo masih menjaga ketradisionalannya, tidak seperti yang berada didaerah Candran kesenian tradisional Nini Thowong sudah dikemas menjadi seni pariwisata. Seperti yang diungkapkan Mbah Paeran seorang pawang di dusun Grudo, bahwa kesenian Nini Thowong yang berada di dusun Grudo masih kental akan ritual yang digunakan seperti pemasukan roh dilakukan di makam, sedangkan menurut Mbah Ponadi seorang pawang didusun Candran, bahwa Nini Thowong yang berada di dusun Candran sudah tidak menggunakan acara ritual yang dilakukan di makam dan kesenian Nini Thowong ini sudah dikemas menjadi seni pariwisata.

Kesenian Nini Thowong sudah ada di Dusun Grudo Desa Panjangrejo, Kecamatan Pundong, Kabupaten Bantul sejak tahun 1938, namun saat pertunjukannya masih sangat sederhana hanya menggunakan kendang dan gong untuk instrumen pengiringnya. Kesenian Nini Thowong pertama kali diciptakan oleh Bapak Udiseda, kemudian diwariskan kepada Bapak Marto, selanjutnya Bapak Asto, dan sekarang diwariskan kepada Mbah Paeran. Permainan Nini Thowong membutuhkan peran serta seorang pawang, karena permainan ini merupakan pemindahan roh halus kedalam boneka Nini Thowong. Bapak Paeran yang merupakan seorang pawang Nini Thowong di Dusun Grudo menjelaskan bahwa tokoh utama didalam permainan ini adalah boneka perempuan. Bentuk Nini Thowong yang berada di dusun Grudo masih menjaga ketradisionalan, masih menggunakan benda-benda bambu, tempurung, gayung, merang, dan busa. Namun, seiring perkembangan zaman bentuk boneka Nini Thowong yang berada di daerah Candran sudah memakai topeng dikarenakan 
kesenian tersebut sudah dikemas menjadi seni pariwisata.

Poerwadarminta dan KBBI (dalam Sujarno, 2002: 228), menyatakan bahwa Nini Thowong terdiri atas dua kata nini dan thowong, Nini dalam bahasa Jawa artinya embah wedok, yaitu orang perempuan yang sudah lanjut usia atau sudah nenek. Sementara Thowong diartikan kosong atau lowong atau terbuka. Pada zaman dahulu Nini Thowong dimainkan pada saat bulan purnawa, namun seiring perkembangan zaman Nini Thowong sekarang dimainkan jika ada permintaan dari masyarakat namun tradisi ritual masih dilakukan sampai saat ini, yang berbeda hanya waktu pertunjukannya saja.

Pada zaman dahulu sampai sekarang Nini Thowong bukan sekedar permainan biasa, tetapi merupakan suatu upacara untuk memanggil hujan, pengobatan, pesugihan, atau mencari barang yang hilang (Dharmamulya, 2004: 107). Nini Thowong tidak bisa berbicara, namun hanya dengan bahasa isyarat mengangguk ataupun menggeleng. Pada saat pertunjukan Nini Thowong, ada ritual tersendiri yaitu pengambilan roh dilakukan di makam yang berada di dusun Grudo, hiasan bunga diambil dari makam, sesaji ritual berupa (telor, air kembang setaman, kemenyan), dan menggunakan lagu-lagu tertentu untuk mengundang roh. Syair yang terdapat didalam lagu mupu bocah bajang, bageya, ilir-ilir, ayoayo, hela-helo tersebut memuat pesan atau

\begin{tabular}{|c|c|c|}
\hline \multicolumn{2}{|c|}{ Expression } & Content \\
\hline Expression & Content & \\
\hline konotasi & & \\
\hline
\end{tabular}

makna yang ditunjukkan untuk menasehati atau memberi nasehat kepada penonton. Saat pertunjukan Nini Thowong berlangsung, penonton atau penikmat seni harus menjaga ucapan, sopan santun, tata krama karena jika penonton (ngrasani) maka Nini Thowong akan marah dan akan memukul orang tersebut.

\section{Semiotika Sistem Mitos Roland Barthes}

Ferdinand de Saussure melihat tanda terdiri dari significant dan signifie (bahasa Prancis), yang dalam bahasa Inggris menjadi signifier dan signified. Barthes menggunakan teori significant menjadi ekspresi dan signifie menjadi isi, kemudian dikembangkan menjadi teori tentang metabahasa dan konotasi. Namun Barthes mengatakan bahwa significant dan signifie harus relasi sehingga terbentuk tanda (sign) (Hoed dalam Pradoko 2015:45).

Adanya makna denotatif yang merupakan makna awal antara significant dan signifie proses relasi manusia memunculkan makna konotasi dan metabahasa. Makna konotasi terjadi proses significant (ekspresi), sign (tanda) dan signifie (isi) pada sistem primer menjadi berkembang adalah isinya pada sisitem sekunder. Makna metabahasa terjadi proses significant (ekspresi), sign (tanda) dan signifie (isi) pada sistem primer menjadi significant yang berkembang adalah ekspresinya pada sistem sekunder (dalam Pradoko 2015:45). Berikut ini gambar skema konotasi dan denotasi sebagai berikut.

\begin{tabular}{|c|c|c|}
\hline Expression & \multicolumn{2}{|c|}{ Content } \\
\hline & Expression & Content \\
\hline & Metabahasa & \\
\hline
\end{tabular}

Gambar 1. Bagan Konotasi dan Metabahasa Sistem Sekunder (Bennt H.)

Mitos merupakan suatu proses sistem penandaan. Semiotik mitos dapat diuraikan sebagai tiga unsur yaitu signifier, signified dan sign pada sistem tingkat pertama atau sistem primer. Pada sistem sekunder Barther menggunakan istilah yaitu form, concept, dan signification (Sunardi dalam Pradoko 2015: 56). 


\begin{tabular}{|c|c|c|c|}
\hline \multirow{3}{*}{$\begin{array}{l}\text { Sistem } \\
\text { Primer }\end{array}$} & 1. Signifier & 2. Signified & \\
\hline & \multicolumn{2}{|c|}{ 3. Sign } & \\
\hline & \multicolumn{2}{|l|}{ 1. Signifier } & 2. Signified \\
\hline & \multicolumn{2}{|l|}{ From } & Concept \\
\hline \multirow{2}{*}{$\begin{array}{l}\text { Sistem } \\
\text { Sekuner }\end{array}$} & \multicolumn{3}{|c|}{ 3. sign (signification) } \\
\hline & & & \\
\hline
\end{tabular}

Gambar 2. Skema Sistem Mitos

(Sumber Suardi, dalam Prodoko 2016: 46)

Nini Thowong ini dianalisis menggunakan teori Barthes tentang Mitos.Barthes berpendapat bahwa berbicara mitologi terdapat dua sistem signifikasi, denotasi dan konotasi. Denotasi adalah level makna deskriptif dan literal yang secara virtual dimiliki semua anggota suatu kebudayaan sedangkan konotasi itu merupakan makna yang terbentuk dengan mengaitkan petanda dengan aspek-aspek kultural yang lebih luas; keyakinan, sikap, kerangka kerja dan ideologi suatu formasi sosial.

Mitos adalah konstruksi kultural, tetapi ia bisa tampak sebagai kebenaran universal yang telah ada sebelumnya dan sudah melekat pada nalar. Mitos ini mirip dengan konsep ideologi karena sama-sama berkerja pada level konotasi. Bahkan Volosinov (dalam Pradoko 2016: 74), berpendapat bahwa ranah ideologi berkorespondensi dengan arena tanda, dimana ada tanda maka di situ ada ideologi.

Bagi Barthes mitositu merupakan semiologi urutan kedua atau metabahasa. Mitos adalah bahasa kedua yang berbicara tentang bahasa tingkat pertama. Tanda pada sistem pertama (penanda dan petanda) yang membentuk makna denotatif menjadi penanda pada urutan kedua makna dari mitologis konotatif (Pradoko 2016:74).

Menurut Barthes (dalam Pradoko 2016: 75), mitos dan ideologibekerja dengan menaturalkan interpretasi individu yang khas secara historis. Jadi, mitos menjadikan pandangan dunia tertentu itu terjadi secara alamiah yang ditakdirkan Tuhan. Mitos bertugas memberikan justifikasi alamiah kepada maksud-maksud historis dan menjadikan berbagai peristiwa yang tak terduga tampak abadi.

\section{METODE}

Penelitian ini merupakan penelitian deskriptif, yang mendeskripsikan Mitos Nini Thowong. Penelitian ini menggunakan penelitian kualitatif karena bermaksud untuk mendeskripsikan, menginterpretasi dan menganalisis kondisi-kondisi yang terjadi secara mendalam, tanpa mengubah fakta yang terjadi. Penelitian kualitatif juga disebut penelitian naturalistik, yang merupakan penelitian dengan melihat fakta yang ada di lapangan secara apa adanya.

Pendekatan fenomenologi juga dapat digunakan dalam menganalisis mitos. Menurut Endraswara (2003: 42), kata fenomenologi sendiri berasal dari kata fenomena dari bahasa Yunani phainomenan, apakah yang terlihat. Pendekatan fenomenologi dipergunakan untuk menangkap fenomena yang nampak di depan mata dapat dicerna fenomena itu secara kenyataan. Melihat fenomena adalah berpikir untuk menghasilkan yang dialami secara kenyataan. Fenomenologi berupaya untuk memberikan deskripsi tentang pengalaman manusia, mengenai ilmu, teknologi, seni, budaya, yang mengungkapkan bagaimana fenomena-fenomena itu pada dasarnya.

Penerapan fenomenologi dalam seni pertunjukan adalah ketika fenomena sosial atau gejala sosial yang bisa bersifat sosiologis masuk dalam dunia seni pertunjukan. Fenomena sosial itu menjadi proses kesadaran para pelakunya untuk menekan, menghegemoni (bentuk penguasaan), medominasi, menindas, dan mencampakkan kesenian. Ketika terjadinya permasalahan (gejala sosial masuk) dalam kesenian, itu menjadi sorotan dalam pendekatan fenomenologi (Sutiyono, 2011: 116). Pendekat- 
an fenomologis mengungkap bagaimana para pelaku gejala sosial itu bertindak (action). Mengungkap sebuah gejala yang dinamis yang terjadi pada mitos permainan Nini Thowong. Melihat fenomena yang terjadi sebelum boneka Nini Thowong ini dimainkan seorang pawang akan memasukan roh boneka di kuburan.

\section{HASIL DAN PEMBAHASAN}

Permainan tradisional dalam masyarakat Jawa terdapat beberapa permainan yaitu permainan yang bersifat sakral (suci) dan bersifat profan (biasa) (Hermawan dan Abraham, 2017: 128). Menurut Overback (dalam Hermawan dan Abraham 2017: 128), mengatakan mengklasifikasi permainan anak Jawa dibagi menjadi tiga kategori yaitu: 1) permainan biasa, 2) permainan Nini Thowong, dan 3) permainan gaib lainya. Salah satu permainan yang bersifat mistis yang masih bisa bertahan yaitu permainan Nini Thowong di dusun Grudo. Permainan didaerah lain dikenal dengan Nini Thowok, Nini Edhok, Nini Dhiwut, Cowongan, Jailangkung (Suwardi 2008: 3).

Pada masa dahulu Nini Thowong sebenaranya digunakan untuk suatu upacara memanggil hujan, pengobatan, pesugihan, atau mencari barang yang hilang (Dharmamulya dalam Suwardi, 2008: 3). Pertunjukan kesenian Nini Thowong bisa disebut pertunjukan tradisional yang merupakan permainan perpindahan roh halus kedalam boneka Nini Thowong. Nini Thowong adalah permainan pertunjukan boneka yang direka sedemikian rupa yang menyerupai manusia. Boneka ini berwujud seorang putri perempuan sehingga disebut dengan Nini. Wawancara dengan Paeran tanggal 10 Mei 2017, mengatakan bahwa Nini Thowong tidak dapat berbicara biasanya mengangguk dan menggelenggeleng. Tanda tersebut mempunyai makna bahwa menggeleng-geleng berarti "tidak" dan mengangguk berarti "ya".

Esensi orang Jawa sudah sejak masa lalu dunia roh itu selalu diyakini bahwa roh atau dunia gaib itu ada dibalik kehidupannya, sehingga orang Jawa berpikir mistis karena ada hubungan manusia dengan kekuatan di luar manusia. Beragam tafsir mengupas sejarah kemunculan Nini Thowong namun yang pasti Nini Thowong muncul sebagai produk imajinasi pada masyarakat lampau sebagai bagian dari sistem sosialisasi. Pada awal kemunculannya Nini Thowong merupakan permaian anak-anak di bulan purnama. Boneka Nini Thowong pun dirangkai dengan sederhana. Bahan-bahannya terdiri dari bambu, tempurung kelapa, jerami, kertas semen dan tali. Dibuat perwujudan orang-orang jenis wanita yang dihias dengan pakaian dan bunga-bunga serta daun-daunan.

Nini Thowong sebenarnya merupakan penggambaran manusia hidup dibumi. Manusia hidup ini terdiri dari rasa atau badan dan roh atau nyawa. Manusia bisa tumbuh dan berkembang bila dalam tubunya ada rohnya atau dengan kata lain manusia bisa bergerak bila masih ada roh di dalam tubuhnya (Sujarno, 2002: 232). Begitu pula Nini Thowong ada persamaannya yaitu bila roh yang menempati badannya atau raga itu pergi (tidak ada) maka tidak akan bisa bergerak.

Boneka Nini Thowong itu bisa bergerak dimintakan bantuan oleh roh. Yang mengundang roh adalah seorang pawang. Dalam Nini Thowong adanya kekuatan supranatural ini yang bukan menjadi sekedar boneka semata akan tetapi berkembang menjadi sebuah pertunjukan sarat dengan mistis dan digunakan untuk media konsultasi untuk menunjukan ramuan obat-obatan di kala ada warga yang sedang menderita penyakit. Masyarakat terkadang ada yang bilang memelihara Nini Thowong itu musyrik. Menurut Suwardi mengatakan orang Islam yang sudah modern dan masih agak keras menganggap kejadian-kejadian di dunia Nini Thowong dianggap musyrik dianggap bertentangan dengan keagamaan.

Nini Thowong merupakan media penyampaian pesan keagamaan lewat lagu yang dinyanyikan yaitu salah satunya lagu Ilirilir sebagai pengiring permainan. Pada zaman dulu permainan Nini Thowong hanya diiringi lagu dan tepuk tangan.

Untuk memecahkan permasalahan penelitian tentang objek kebudayaan material yaitu Nini Thowong yang akan dianalisis 
dengan sistem mitos dari Roland Barthes. Agar lebih mudah proses penguraian maka dibuat bagian analisis semiotika mitos kesenian Nini Thowong sebagai berikut:

Roland Barthes mengungkapkan adanya sistem pemaknaan primer dan sekunder, misalnya kesenian Nini Thowong sebagai media isyarat pencarian obat dengan melakukan serangkaian pertunjukan dengan bantuan roh. Nini Thowong tidak hanya untuk penyembuhan penyakit tetapi sebagai permainan tradisional. Nini Thowong adalah permainan pertunjukan bonekayang direkasedemikianrupamenyerupai manusia.Dalam pertunjukannya boneka Nini Thowong dimasukan roh oleh pawang dan dimainkan oleh ibu-ibu yang kemudian boneka tersebut bergerak dengan sendirinya yang dipimpin oleh pawang. Ini merupakan makna secara denotasi. Selanjutnya Nini Thowong dalam masyarakat pendukungnya terdapat sistem mitos dimana Nini Thowong merupakan gagasan representasi sebagai media pencarian obat.

Tabel 1. Bagan Semiotika Sistem Mitos Kesenian Nini Thowong

\begin{tabular}{|c|c|c|}
\hline $\begin{array}{l}\text { Signifier } \\
\text { Nini Thowong } \\
\end{array}$ & $\begin{array}{l}\text { Signified: Pertunjukan } \\
\text { kesenian Nini Thowong } \\
\text { bisa disebut pertunjukan } \\
\text { tradisional yang merupakan } \\
\text { permainan perpindahan roh } \\
\text { halus (kedalam boneka Nini } \\
\text { Thowong. }\end{array}$ & $\begin{array}{l}\text { (Sistem } \\
\text { Primer) }\end{array}$ \\
\hline \multirow[t]{2}{*}{ Sign: Nini Thowong } & & Sekuder \\
\hline & & \multirow[b]{2}{*}{$\begin{array}{l}\text { Kesenian Nini Thowong sebagai media } \\
\text { isyarat pencarian obat dengan melakukan } \\
\text { serangkaian pertunjukan dengan bantuan } \\
\text { roh yang dimasukan oleh pawang. Nini } \\
\text { Thowong tidak hanya untuk penyembuhan } \\
\text { penyakit tetapi sebagai permainan } \\
\text { tradisional. Dimainkan oleh ibu-ibu yang } \\
\text { kemudian boneka tersebut bergerak dengan } \\
\text { sendirinya yang dipimpin oleh pawang } \\
(\text { Concept). }\end{array}$} \\
\hline From: Nini Thowong & & \\
\hline (signification) Pawang & & \\
\hline
\end{tabular}

Pada sistem primer makna denotasi, Nini Thowong (signifier) adalah (signified) boneka Nini Thowong yang terbuat dari jerami yang berbentuk memanjang. Kepala terbuat dari batok kelapa dan digambari muka manusia dengan kapur atau jelaga yang berwarna hitam dan putih yang berarti penggambaran pada diri manusia yaitu sifat baik yang dilambangkan dengan warna putih dan buruk dengan warna hitam, sedangkan pada sistem sekunder, sistem primer (Nini Thwong) diambil alih sepenuhnya berwujud seperti memedi sawah. Pada sistem sekunder ini Barthes memberi nama From bukan Sign untuk membedakan hal yang pertama. Nini Thowong (from) berarti representasi kesenian Nini Thowong sebagai media isyarat pencarian obat dengan melakukan serangkaian pertunjukan dengan bantuan roh 
yang dimasukan oleh pawang. Nini Thowong tidak hanya untuk penyembuhan penyakit tetapi sebagai permainan tradisional. Nini thowong dimainkan oleh ibu-ibu, yang kemudian boneka tersebut bergerak dengan sendirinya yang dipimpin oleh pawang (Concept). From dan konsepnya menyatu melalui sistem mitos yang diterima oleh masyarakat pendukungnya. Pawang menjadi kuncinya untuk memasukan roh ke dalam boneka Nini Thowong dan menangani/memimpin pelaku kesenian tradisional tersebut.

Hal yang menarik terhadap kesenian Nini Thowong yaitu adanya aspek mistik dengan masukan roh kedalam boneka tersebut, berdasarkan penuturan Mbah Paeran kesenian ini dipentaskan dalam upacara tradisi bersih desa, hajatan, dan selamatan. Kesenian Nini Thowong ini mengindikasikan memiliki relevansi yang dianut oleh masyarakat pendukung karena dianggap bisa untuk petunjuk pengobatan orang sakit dan kesejahteraan masyarakat Grudo.

Sejalan dengan keberadaan seni sejak zaman primitif, pada saat itu seni banyak mengambil peranan dalam aktivitas atau tujuan yang bersifat sosial maupun religius. Kecenderungan tersebut membuat manusia hidup dengan penuh keinginan-keinginan hidup dengan nyaman, tenang tanpa gangguan apa pun. Keinginan mereka tidak bisa selalu terpenuhi, terkadang mereka menginginkan sesuatu yang tidak bisa dijangkau oleh akal. Hal ini terlibat dalam kepercayaan mereka terhadap mahkluk halus. Soal-soal hidup yang tidak bisa dipecahkan dengan akal dipecahkan dengan magis yang disebut dengan ilmu gaib (Koentjaraningrat, 1985: 223). Masyarakat Jawa yang percaya bahwa alam itu didiami oleh makluk-makluk halus, maka mulailah ia mencari hubungan dengan makhluk-mahluk halus yang mendiami alam itu (Koentjaraningrat, 1984: 64). Untuk menciptakan kondisi yang harmonis antara jagad gedhe dan jagad cilik mereka melakukan hubungan yang saling membantu dan berkerjasama dengan kerukunan tersebut sehingga tercipta keseimbangan yang harmonis.
Pementasan kesenian Nini Thowong ini melakukan praktek ritual dengan membuat sesaji sebagai perwakilan atas keingian mereka. Menurut Suehardi, sesaji memiliki sifat mistis dan sekaligus bermakna simbolis. Sesaji mempunyai arti memberikan sesuatu dalam bentuk makanan. Tujuan pemberian sesaji itu adalah bentuk dari persembahan kepada para mahkluk roh halus yang bersemayam disuatu tempat misalnya di kuburan. Diberikan sesaji agar roh itu datang dan masuk ke dalam boneka Nini Thowong, upacara memasukan roh ini di dilakukan oleh Pawang. Menurut Soehardi berbagi bentuk sesaji mempunyai makna simbolik. Sesaji yang digunakan untuk pemanggilan roh Nini Thowong antara lain dapat dilihat dalam gambar 2 .

Selain adanya sesaji yang digunakan, dalam pertunjukan Nini Thowong ada nyanyian/lagu pokok yang dinyanyikan pada awal pertunjukan itu dimulai, hal ini terdapat makna dibalik itu semua. Lagunya antara lain Ayo Мuри Bocah Bajang, Bageya-bageya Mbok Lara Lagi Teka, Ilir-ilir. Berikut ini akan dijelaskan makna dibalik lagu dapat dilihat pada gambar 3 .

Selain itu bonekaNini Thowong mempunyai makna tersendiri dapat dilihat pada gambar 4 .

Kesenian Nini Thowong merupakan jenis pertunjukkan kesenian ritual yang mempunyai nilai bagi masyarakat serta melibatkan energi supranaturaldenganmahklukhalus. Masyarakat Grudo memahami dan meyakini mitos yang terdapat pada kesenian Nini Thowong sebagai media untuk mencarikan obat untuk orang sakit, kesejahteraan dan rejeki masyarakat meningkat dan kesenian ini masih ditradisikan oleh masyarakatnya sampai sekarang ini.

Mitos merupakan salah satu bagian dari cerita rakyat yang hampir selalu muncul dalam berbagai aktivitas sosial keagamaan masyarakat.Mitos juga dianggap mengandung pesan-pesan moral bagi masyarakat yang meyakininya (Ayatullah, 2012: 159). Kesenian Nini Thowong memunculkan mitos agar masyarakat yakin bahwa yang dimitoskan mempunyai nilai sakralitas yang tidak boleh diremehkan apalagi diruntuhkan dan dihancurkan. Tihami (dalam Ayatullah, 2012: 


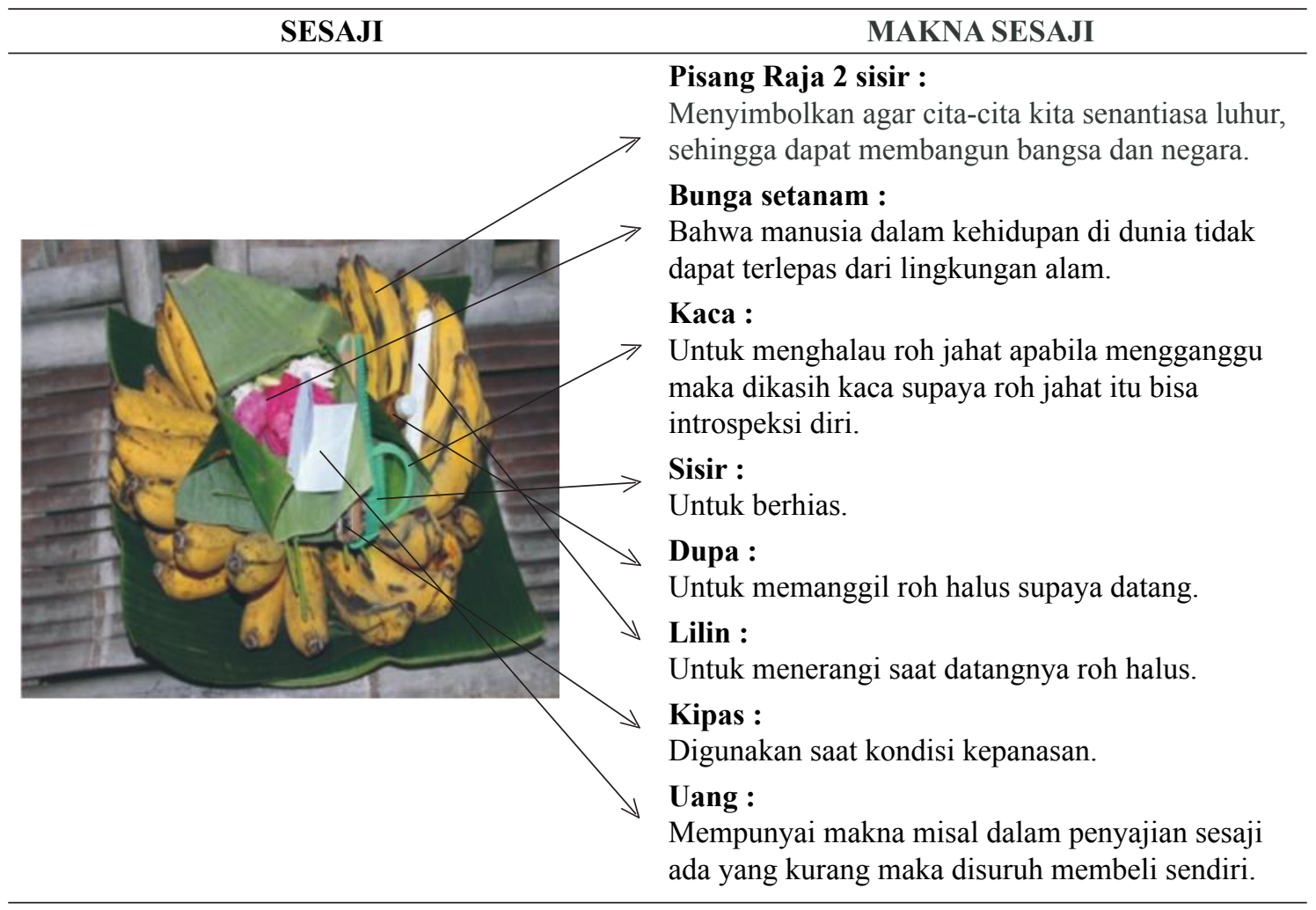

Gambar 2. Sesaji Kesenian Nini Thowong

160-161), menyatakan bahwa mitos adalah cerita suatu bangsa tentang dewa dan pahlawan zaman dahulu, yang mengandung penafsiran tentang asal-usul semesta alam, manusia, dan bangsa itu sendiri serta mengandung arti mendalam yang diungkapkan dengan cara gaib. "Mitos menceritakan sebuah sejarah yang sakral; menghubungkan suatu kejadian yang terjadi di masa purba, zaman permulaan. Mitos hanya menjelaskan dari apa yang betulbetul terjadi, yang memanifestasikan dirinya sendiri secara komplit (Eller dalam Ayatullah, 2012:165).

Berdasarkan penjelasan tersebut, jelas bahwa suatu cerita dikatakan mitos apabila ada unsur atau nilai kesakralan dalam cerita itu dan diyakini atau dianggap benar oleh masyarakat atau dianggap pernah terjadi di masa lampau. Artinya bahwa cerita-cerita yang tidak memiliki atau tidak mengandung nilai sakral, dan masyarakat menganggapnya hanya sekedar dongeng atau cerita hiburan saja, tidak lagi dianggap sebagai mitos, tetapi barangkali hanya dianggap sebagai cerita rakyat (folklore). Mitos memainkan peran penting dalam kehidupan sosial. Mitos dapat membangun solidaritas sosial masyarakat yang bersangkutan. Mitos yang mereka percayai memiliki sakralitas dan mengandung pesan moral yang diwariskan dari leluhur-leluhur mereka. Selanjutnya, cerita yang ada dalam mitos juga dapat menjelaskan kondisi ekonomi dan kehidupan sosial sebuah suku serta dapat mengungkap beragam bahaya, ketidakberuntungan, serta penyakit yang disebabkan oleh hal-hal gaib. Sehingga, ketika ada suatu ritual yang harus dijalani oleh masyarakat yang bersangkutan untuk menghindari bahaya dan penyakit yang dijelaskan dalam mitos tersebut, mereka akan menjalaninya secara kolektif dengan kesadaran bersama untuk melindungi masyarakatnya dari bahaya-bahaya gaib tersebut. Berkaitan dengan ini, Kluckhon, seperti dikutip oleh Bustanudin yang melakukan penelitian tentang suku Pueblo dan Navajo di kalangan orang Indian, selain menemukan penjelasan tentang 


\begin{tabular}{|c|c|}
\hline DAFTAR LAGU & MAKNA LAGU \\
\hline $\begin{array}{c}\text { Ayo Mupu Bocah Bajang } \\
\text { Rambute arang-abang } \\
\text { (Mari mengadopsi anak bajang } \\
\text { rambutnya jarang dan berwarna } \\
\text { merah) }\end{array}$ & $\begin{array}{l}\text { Bahwa dalam kehidupan di masyarakat manusia tidak lepas dari } \\
\text { lingkungan sosialnya. Ini tampak dari syair lagu yang merupakan } \\
\text { ajakan kepada orang untuk ikut memperhatikan anak bajang atau } \\
\text { anak yang kurang mampu. Hal ini mempunyai makna yang sangat } \\
\text { mendalam terhadap masyarakat pemangku kebudayaan tersebut. } \\
\text { Ini merupakan peringatan bagi manusia supaya tidak mengabaikan } \\
\text { perkembangan generasi mudanya. Sebab masa depan suatu } \\
\text { masyarakat itu selain tidak hanya tergantung generasi tua, yang } \\
\text { terpenting adalah bagaimana keadaan generasi muda atau penerusnya. } \\
\text { Dengan demikian syair lagu tersebut mempunyai nilai yang cukup } \\
\text { penting bagi masyarakat. }\end{array}$ \\
\hline $\begin{array}{c}\text { Bageya-bageya Mbok Lara Lagi } \\
\text { Teka }\end{array}$ & $\begin{array}{l}\text { Sebuah ajakan supaya manusia dalam bertindak tidak tergesa-gesa, } \\
\text { mau menunggu untuk sementara waktu. Hal ini tampak pada syair } \\
\text { lagu yang berbunyi mbok lara lagi teka. Kata lara bisa diarttikan } \\
\text { sakit. Namun karena depannya terdapat kata mbok, tampaknya kata } \\
\text { lara itu untuk menyebut orang perempuan misalnya anak dipedesaan } \\
\text { yang menyebut ibunya dengan kata mbok. Dengan kata lain lagu } \\
\text { bageyayang dilantunkan berulang mempunyai makna yaitu mengajak } \\
\text { manusia untuk memiliki sifat sabar dan juga tepasliraatau rasa } \\
\text { toleransi terhadap sesamanya. }\end{array}$ \\
\hline Ilir-ilir & $\begin{array}{l}\text { Mengingatkan manusia tentang adanya kehidupan lain yang akan } \\
\text { dihadapi. Dalam hidupnya, manusia supaya mempunyai keseimbangan } \\
\text { antara kebutuhan rohani dan jasmaninya. Disini manusia diingatkan, } \\
\text { mumpung padang rembulane, mumpung jembar kalangane, yaitu } \\
\text { mumpung masih mempunyai waktu dan mempunyai kesempatan } \\
\text { hal-hal yang tidak benar supaya diperbaiki. Masih ada kesempatan } \\
\text { untuk menyeimbangkan antara kebutuhan jasmani dengan rohaninya. } \\
\text { Hal ini dimaksudkan sebagai bekal menghadapi maut, menghadapi } \\
\text { kehidupan selanjutnya yaitu kehidupan di akhirat di mana semua yang } \\
\text { dilakukan selama di dunia dipertanggungjawabkan kepada Tuhan. }\end{array}$ \\
\hline
\end{tabular}

Gambar 3. Daftar Lagu Pokok Nini Thowong

ekonomi dan kehidupan sosial pada suku tersebut, juga mengungkap bahaya-bahaya gaib, seperti penyakit yang dipandang sebagai hukuman. Mereka melakukan ritual penting untuk melindungi diri dari penyakit. Ritual itu juga berfungsi untuk mengungkap solidaritas dan respons bersama terhadap bahaya tersebut. Dengan demikian, mitos adalah suatu kekuatan yangmembantumelestarikan wujud masyarakat (Bustanudin dalam Ayatullah, 2012: 168).

Padahal sebenarnya, mitos bukan hanya terjadi dan dipercayai oleh masyarakat tradisional saja, masyarakat modern pun, terutama masyarakat yang tinggal di desa, masih mempercayai akan adanya mitos-mitos di lingkungan mereka. Meskipun kebenaran fakta dari mitos ini sulit untuk dianalisis dan diobservasi secara ilmiah, sebagian masyarakat masih meyakini keberadaan dan kesakralan mitos tersebut (Ayatullah, 2012: 164).

Roh yang biasanya memasuki boneka Nini Thowong adalah roh perempuan yang dipercaya masyarakat orang yang juga tinggal di dusun Grudo tersebut. Menurut wawancara dengan mbah Paeran (12 Mei 2017), Roh yang masuk dalam boneka Nini Thowong ada dua macam, biasanya roh baik dan roh jahat. Roh baik yaitu roh yang biasa masuk dalam boneka Nini Thowong, sedangkan roh jahat itu masuk jika ada penonton yang ngerasani dan yang nantinya boneka Nini Thowong tersebut akan menabrakkan badannya ke penonton yang ngerasani. 


\begin{tabular}{ll}
\hline BONEKA NINI THOWONG & \multicolumn{1}{c}{ MAKNA } \\
\hline & $\begin{array}{l}\text { Aksesoris Bunga : } \\
\text { Pengambilan di kuburan, dan mempunyai makna bahwa } \\
\text { terlepas dari alam sekitarnya. }\end{array}$ \\
& $\begin{array}{l}\text { Wajah dari Tempurung Kelapa : } \\
\text { Tempurung kelapa digambar dengan muka manusia } \\
\text { dengan kapur atau jelaga yang berwarna hitam dan putih. } \\
\text { Penggambaran ini menunjukkan bahwa manusia mempunyai } \\
\text { fisik baik tetapi sekaligus buruk. Dengan kata lain, dalam } \\
\text { diri manusia terdapat sifat baik yang dilambangkan dengan } \\
\text { warna puth dan buruk dengan warna hitam. }\end{array}$ \\
& $\begin{array}{l}\text { Pakaian : } \\
\text { Menggunakan pakaian perempuan Jawa, karena roh yang } \\
\text { terdapat didalam Nini Thowong roh perempuan. Dan } \\
\text { merupakan pakaian terbuat dari kain yang mempunyai sifat } \\
\text { duniawi. Artinya manusia dihinggapi duniawi, baik yang } \\
\text { berupa harta benda (kekayaan) maupun derajat pangkat. }\end{array}$ \\
\hline
\end{tabular}

Gambar 4. Boneka Nini Thowong

Mitos berkaitan dengan sesuatu yang dipercaya sebagai hal yang sakral. Masyarakat Grudo tidak beranggapan musyrik untuk mempercayai mitos tentang kesenian Nini Thowong, mungkin hanya ada beberapa orang yang beranggapan musyik. Karena setelah mencari beberapa informasi masyarakat Grudo mempercayai bahwa adanya pementasan kesenian Nini Thowong membawa kemakmuran dan rejeki masyarakat setempat semakin meningkat.

Adanya mitos terhadap kesenian Nini Thowong ini sebagai tradisi lisan perlu dipertahankan, walaupun saat ini pula tradisi tulis telah digalakkan. Karena mitos berfungsi untuk menampung dan menyalurkan aspirasi, inspirasi dan apresiasi masyarakat. Barthes juga menggaris bawahi bahwa tuturan mitologis dibuat untuk komunikasi dan mempunyai suatu proses signifikasi yang dapat diterima oleh akal sesuai dengan situasi dan kondisi masing-masing pada kehidupan sosial budaya masyarakat pendukungnya.

Budaya Jawa yang ada di Yogyakarta merupakan manipretasi dari filosofi atau cara pandang terhadapaspek-aspek dalamkehidupan masyarakat dan tidak mengesampingkan aspek-aspek alamnya. Seni pertunjukan yang tercipta pada masa lalu dan masih tersisa hingga masa sekarang merupakan cerminan masyarakat Jawa yang tersampaikan dengan cara-cara yang indah. Namun, sarat dengan pesan-pesan kearifan lokal. Nini Thowong salah satu permainan tradisional yang merupakan perwujudan metafora hubungan manusia Jawa dan alamnya baik yang bersifat konkrit maupun abstrak.

\section{KESIMPULAN}

Kesenian Nini Thowong merupakan seni pertunjukan pemasukan roh ke dalam boneka Nini Thowong, kemudian boneka tersebut menari dengan di mainkan empat orang wanita guna memegangi Nini Thowong. Boneka tersebut menari sebagaimana mestinya sebagai seorang penari. Gerak-gerak tariannya sangat abstrakseperimengeleng-geleng, menganggukngangguk, berputar, loncat-loncat dan apabila ada penonton yang ngerasani maka Nini Thowong tersebut akan marah dan memukul penonton tersebut. Kesenian Nini Thowong ini dianggap memiliki mitos sebagai petunjuk 
pengobatan, kesejahteraan, dan meningkatnya rejeki masyarakat sekitar dusun Grudo. Mitos ini sampai sekarang masih diyakini oleh masyarakat dusun Grudo.

\section{DAFTAR PUSTAKA}

Ayatullah, Humaeni. 2012. Makna Kultural Mitos dalam Budaya Masyarakat Banten. Indonesian Journal of Social and Cultural Anthropology.Vol 33 No 3 SeptemberDesember, hal 159-180.

Barthes, Roland. 1973. Pertualangan Semiologi (Terjemahan Wening Udasmoro Le Plaisir du Takte) Paris: Editions du Seuil.

Fransiskus, Simon. 2006. Kebudayaan dan Waktu Senggang. Yogyakarta: Jalasutra

Hermawan Hendra \& Abraham. 2017. Fungsi Permaian Remaja Nini Dhiwut Dusun Gerbang Sananwetan Blitar (Kajian Makna Semiotik dan Nilai-nilai Edukasi). Agastya Vol 7 No 1 Januari, hal 127-151.

Koentjaraningrat. 1985. Beberapa Pokok Antropologi Sosial. Yogyakarta : Rakyat Balai Pustaka. 1984. Kebudayaan Jawa. Jakarta:

Peursen, C.A. van 1993. Cultur in Stroomversnelling-een gehell bewerkte uitgave van Strategie Van De Culturr, diterjemahkan Dick Hartoko (Strategi Kebudayaan). Cet VI: Yogyakarta: Kanisius.
Pradoko, Susilo. 2016. Program S2 Studi PendidikanSeni Program Pascasarjan UNY. Rader Mata Kuliah Sosio-Antropologi Seni.

2015. Semiotika Guna Penelitian Objek Kebudayaan Material Seni. Imaji Vol 13 No 2 Agustus, hal 41-56.

Suwardi. 2008. SeniSpritual Nini Thowong: Antara Ngelmu Lung, Ngelmu Ling, dan Ngelmu Leng Menuju Pembentukan Kampung Wisata Budaya. Makalah Seminar Internasional Tradisi Lisan Nusantara VI, di Kabupaten Walikota, Sulawesi Tenggara, 1-3 Desember 1-21.

Sujarno. 2002. Permainan Tradisonal Nini Thowong, Fungsi dan Nilainya Bagi Masyarakat. Patra Widya Vol 3 No 3 September, hal 221-255.

Soehardi. 1986. Konsep Sangkan Paran dan Upacara Slametan dalam Budaya Jawa Dalam Berapa Aspek Kebudayaan. Yogyakarta.

Tim Penyusun Kamus Pusat Pembinaan dan Pengembangan Bahasa. 1999. Kamus Besar Bahasa Indonesia. Jakarta: Balai Pustaka 


\section{LAMPIRAN}

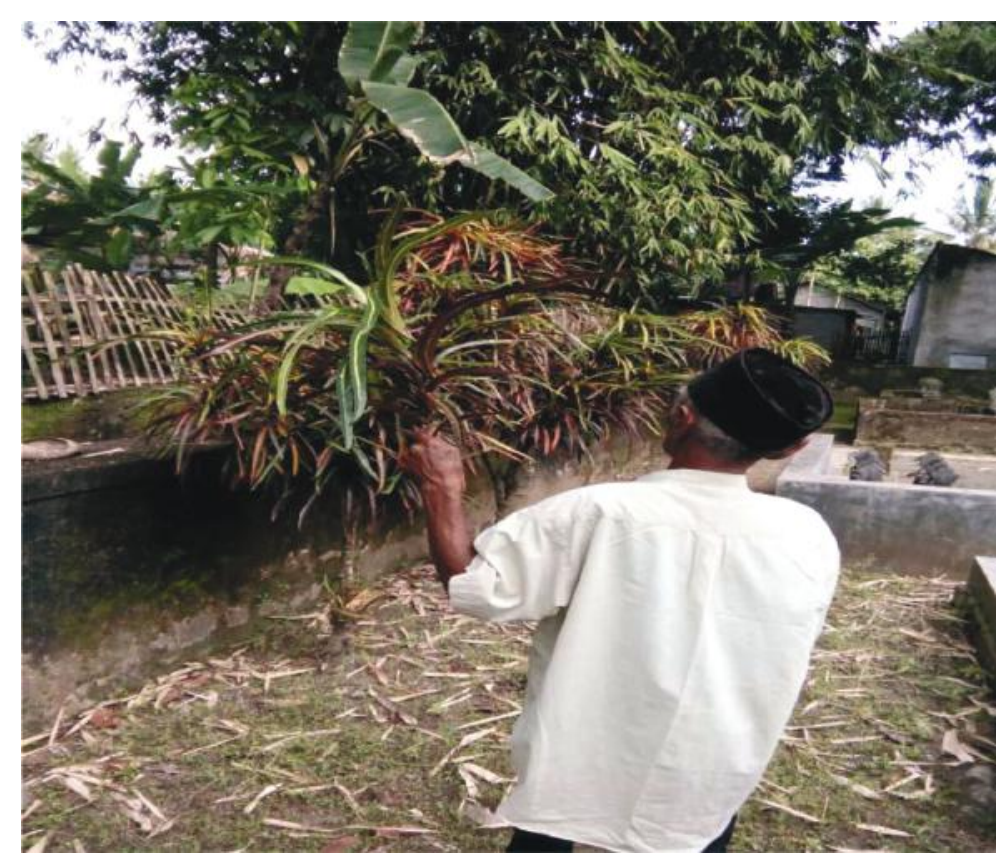

Gambar 1. Pengambilan bunga dilakukan di kuburan

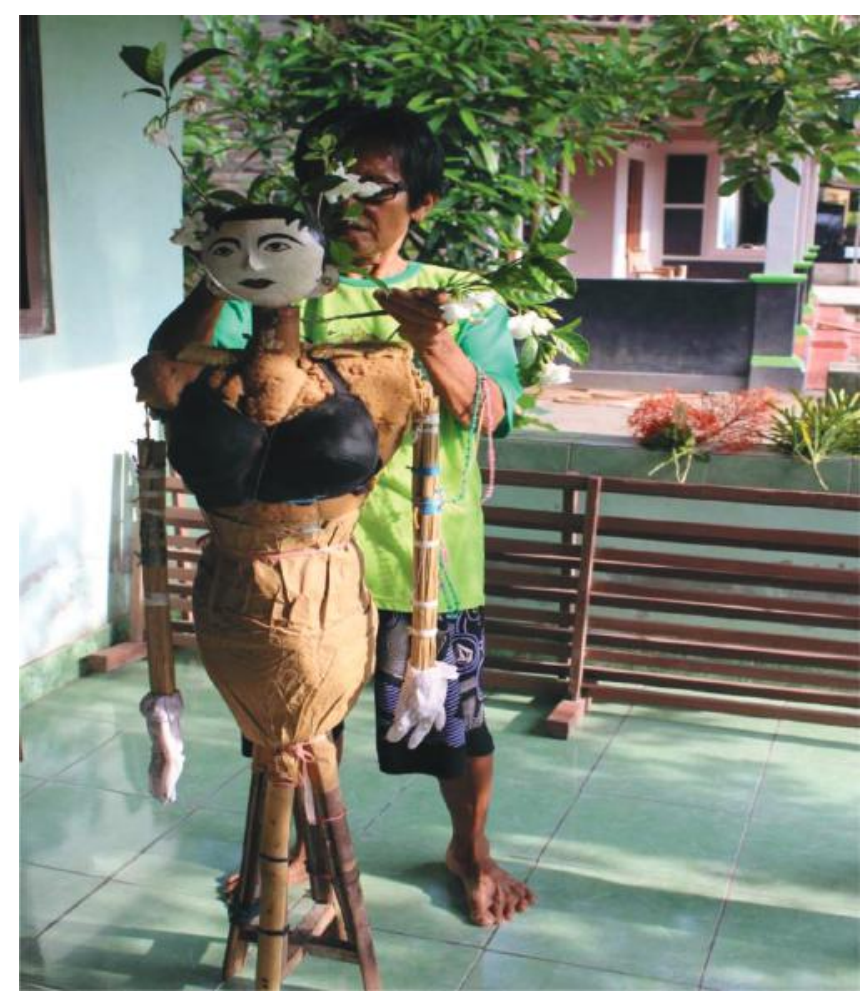

Gambar 2. Proses pemakaian busana Nini Thowong 


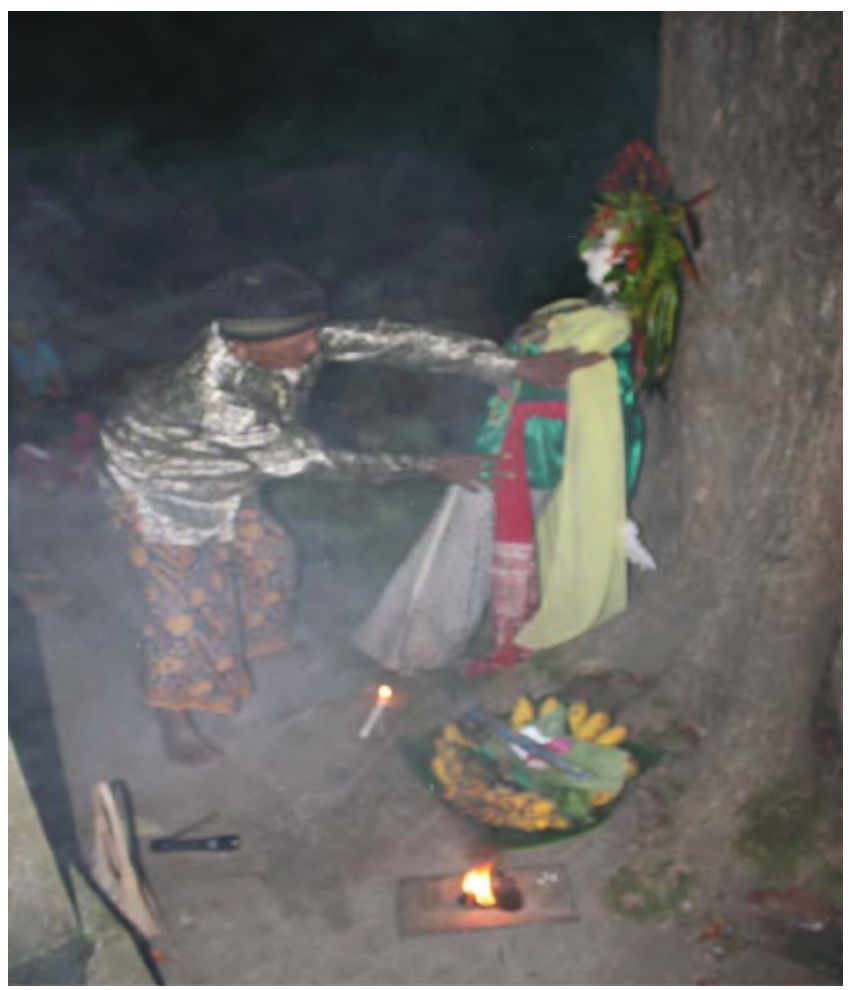

Gambar 3. Pengambilan roh di kuburan

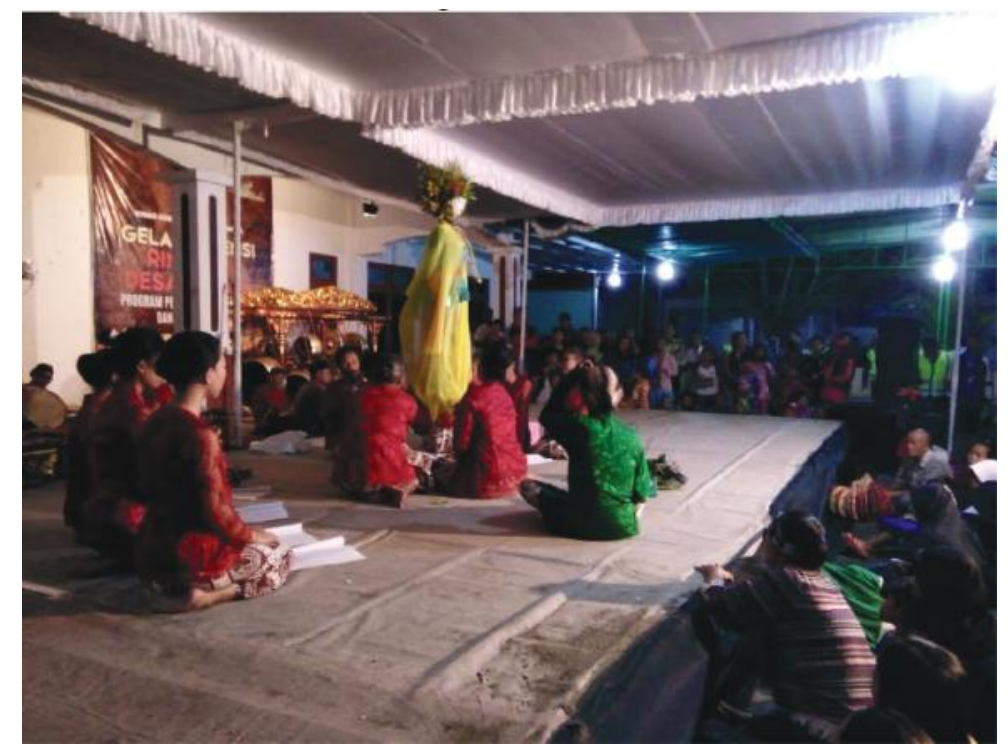

Gambar 4. Pertunjukan Nini Thowong di Kecamatan Grudo 
72 imasi, Vol. 16, No. 1, April 2018: 58 - 72

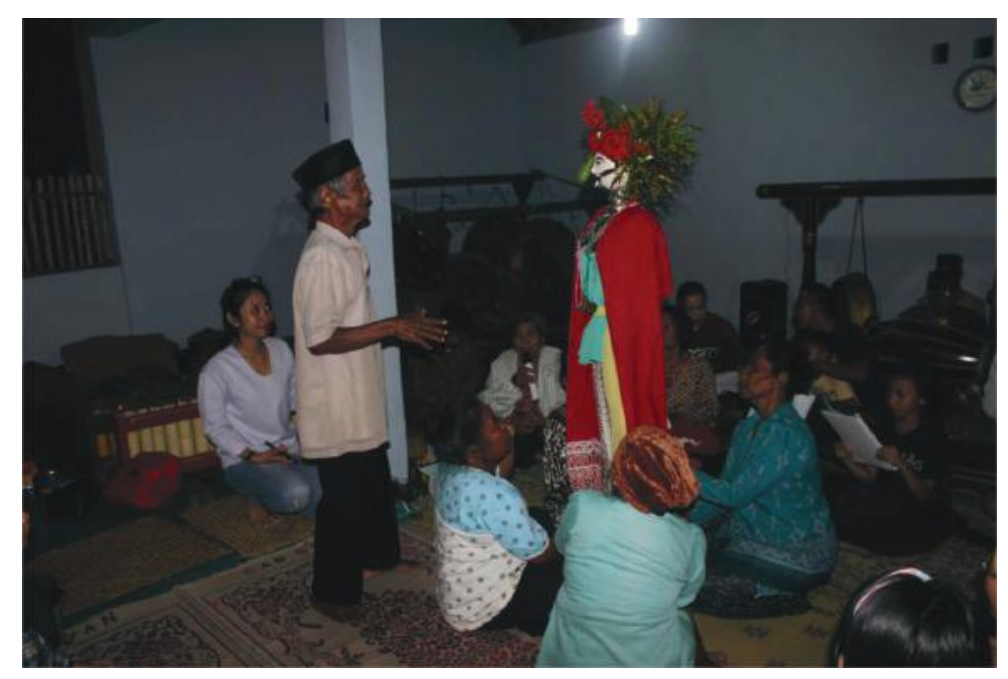

Gambar 5. Pertunjukan Nini Thowong di dusun Grudo

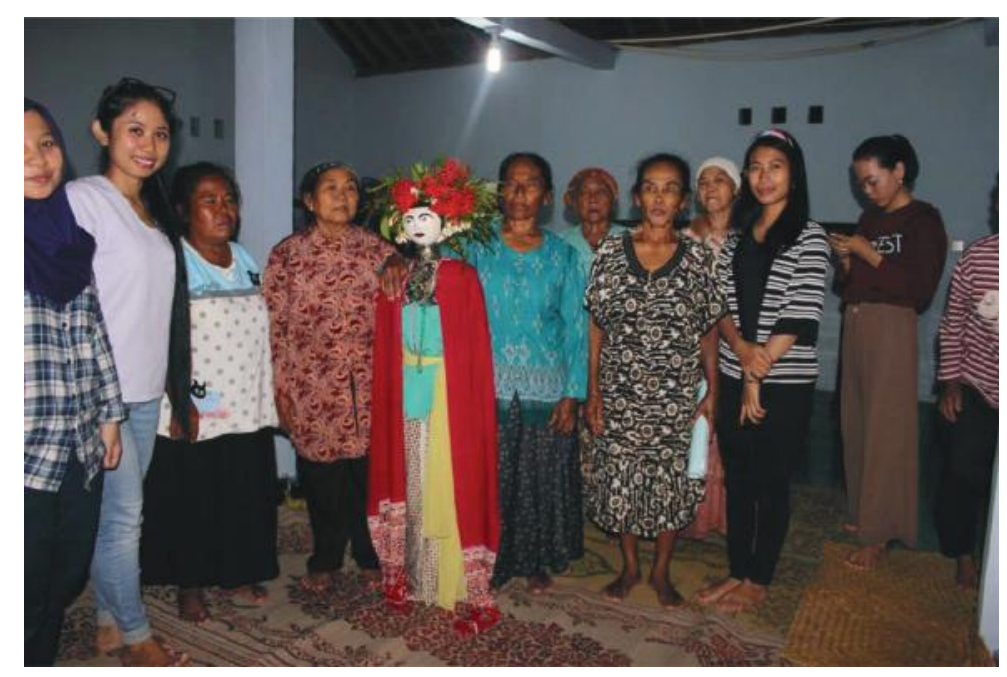

Gambar 6. Anggota kesenian Nini Thowong 